NBER WORKING PAPER SERIES

\title{
WHO GOES TO COLLEGE? \\ DIFFERENTIAL ENROLLMENT BY RACE AND FAMILY BACKGROUND
}

\author{
Sandra E. Black \\ Amir Sufi \\ Working Paper 9310 \\ http://www.nber.org/papers/w9310 \\ NATIONAL BUREAU OF ECONOMIC RESEARCH \\ 1050 Massachusetts Avenue \\ Cambridge, MA 02138 \\ October 2002
}

We would like to thank Mary Daly, Janet Currie, Enrico Moretti, seminar participants at the London School of Economics, the University of Warwick, the Federal Reserve Bank of San Francisco, UC Santa Cruz, and Dartmouth College, and especially Steve Cameron and Paul Devereux for useful comments and discussions. Yigal Gelb provided excellent research assistance. This paper was initiated while the authors were employees of the Federal Reserve Bank of New York. The views expressed herein are those of the authors and not necessarily those of the National Bureau of Economic Research.

(C) 2002 by Sandra E. Black and Amir Sufi. All rights reserved. Short sections of text, not to exceed two paragraphs, may be quoted without explicit permission provided that full credit, including $\odot$ notice, is given to the source. 
Who Goes to College? Differential Enrollment by Race and Family Background Sandra E. Black

Amir Sufi

NBER Working Paper No. 9310

October 2002

JEL No. I2, J0

\begin{abstract}
$\underline{\text { ABSTRACT }}$
While trends in college enrollment for blacks and whites have been the subject of study for a number of years, little attention has been paid to the variation in college enrollment by socioeconomic status (SES). It is well documented that, controlling for family background, blacks are more likely to enroll in college than whites. This relationship is somewhat deceptive, however. Upon closer examination, we find that blacks are more likely to enroll in college than their white counterparts only among low-SES individuals. Among high SES individuals, this pattern is reversed. We also find that this relationship is strongest in the 1970s and appears to disappear over time; by the 1990s, blacks are no more likely to attend college than whites at any end of the SES distribution. This paper first documents this phenomenon and then attempts to understand what is driving these differences across the distribution of family background characteristics and why the relationship is changing over time. Although they have a significant impact on college enrollment behavior, tuition costs and local labor markets explain very little of racial differences in college entry. We do uncover different responses to tuition and labor markets by individuals from different ends of the SES distribution, an important consideration for policies targeted at improving college enrollment for low-SES individuals.
\end{abstract}

Sandra E. Black

Department of Economics

9373 Bunche Hall

UCLA

Los Angeles, CA 90095

and NBER

sblack@econ.ucla.edu
Amir Sufi

Department of Economics

MIT

Cambridge, MA 02138

sufi@mit.edu 


\section{Introduction}

The distinct pattern of college enrollment for blacks in the last three decades has been an important topic of study, with recent evidence suggesting family background and tuition costs as explanations. In the process, a number of researchers have documented the rather surprising fact that in the 1970s and early 1980s, controlling for family background characteristics, blacks were more likely to attend college than equivalent whites. ${ }^{1}$ While a number of papers have examined differing racial enrollment patterns and uncovered this result, very little work has focused on the result itself. To date, this finding remains largely a puzzle.

Upon closer examination, one uncovers the startling observation that blacks at the low end of the family background spectrum are driving this result. That is, low socio-economic status (SES) blacks are more likely than their white counterparts to attend college. At the same time, this story flips at the high end of the SES spectrum; high status blacks are less likely to attend college than equivalent whites. This relationship is strongest in the 1970s and early 1980s and dissipates over time.

The idea that low-SES blacks are more likely than their white counterparts to attend college runs counter to many preconceptions that low-income blacks exhibit the worst labor market performance and educational attainment relative to other groups. Anecdotal evidence often suggests that when blacks exhibit better education, employment, or earnings performance, it is only the already well off that reap the lions share of benefits. Indeed, these views are supported if one looks at other outcomes; Bound and Freeman (1992), among others, document the erosion of relative earnings and

${ }^{1}$ See for example Cameron and Heckman (2001), Hauser (1993), Catsiapis (1987), and Rivkin (1995). 
employment among blacks in the 1980s, noting that the wages of low-educated workers fell but the wages of low-educated black workers fell by more than the wages of their white counterparts. In college enrollment, however, our findings prove false many prior beliefs about racial differences in postsecondary education. During the 1970s and 1980s, out of all groups of blacks, those blacks at the low end of the SES distribution, regardless of how SES is measured, exhibit the strongest college enrollment behavior relative to their white counterparts.

We then turn to possible explanations for this pattern. What becomes clear is that patterns of college enrollment differ not only across races, but also across individuals with different family background characteristics. We focus primarily on the role of college costs and the idea that not only do blacks and whites face different labor markets, but that individuals from different family backgrounds respond differently to their local conditions. We conclude that individuals do respond to differences in college costs and that increases in college tuition have disproportionately affected blacks at the low end of the SES distribution. However, these differential responses explain little of the total variation in college enrollment rates between blacks and whites. Despite this, these findings provide insight into appropriate policies to increase college attendance among the less advantaged.

This paper unfolds as follows. Section II frames the problem we are addressing. Section III describes our data. Section IV establishes the basic patterns in black-white college-entry behavior, while Section V investigates the determinants of college entry using more rigorous tools. Section VI concludes.

II. Previous Literature on Black-White College Enrollment 
Black college enrollment has followed an interesting path since the early 1970s (Figure 1). In the late 1970s, black college enrollment increased dramatically, approaching the enrollment rate of whites. In the early 1980s, however, there was a severe drop off. Since that time, black and white college entrance rates have diverged, with blacks falling farther behind.

Both Kane (1994) and Hauser (1993) study the time-series patterns of college enrollment in the CPS. $^{2}$ They find that parental family background is the most significant factor in explaining both the time-series and cross-sectional differences in the data. They assign a secondary role to college tuition, Federal subsidies to college-attenders (the most well-known of which is the Pell Grant program), and labor market variables. The importance of family background has also been documented in a number of other important studies. Fuller, Manski and Wise (1982) and Cameron and Heckman $(1998,2001)$ are examples of this work. Like Kane (1994) and Hauser (1993), Cameron and Heckman (2001) analyze black-white differences in college entry (the latter two papers also look at Hispanic-white differences).

On the cross-sectional front, Rivkin (1995) documents that, in the High School and Beyond Class of 1982, blacks are more likely to attend college than whites with similar math and verbal test scores. He finds that fewer job opportunities for blacks offer a partial explanation, where local labor market conditions are calculated separately by race and gender.

Our study makes three contributions to this literature. First, we establish not only that blacks and whites exhibit college-entry behavior that is different and statistically distinct but also that looking at

\footnotetext{
${ }^{2}$ Kane (1994), has tried to explain this trend by focusing on college costs and family background. He finds that the rising cost of college during the 1980s discouraged black college entry, whereas the gains in parental education encouraged black college entry. The net effect is the decline and recovery observed in the 1980 s.
} 
mean predicted differences between whites and blacks--as do Kane (1994), Hauser (1992), Rivkin (1995), and Cameron and Heckman (2001)Bfails to reveal important differences in college entry behavior between blacks and whites across the socio-economic spectrum. We also examine how this relationship has changed over time. Second, we conclude that the effects of college tuitionBdespite its dramatic real increase throughout the 1980s and early 1990sBcan account for very little of the blackwhite gap in college entry. Finally, we find evidence that suggests that individuals from different family background respond differently to local labor markets and tuition; as a result, policies that target lessadvantaged youth, both black and white, for college attendance must incorporate these different responses.

III. Data

Because we are focusing on both the cross-section and time-series patterns of black and white college entry for men and women, a large data set that provides consistent measures of college going behavior over time is needed. As a result, our primary data source is the March supplement to the Current Population Survey (CPS) from 1968 through 1998. Because this is a household-based dataset, we are able to match 18 and 19 year olds to their parents as long as they are considered members of the same household. While this may sound restrictive, individuals are considered members of their parent's household as long as they either live in their parents=household or live in group quarters away from the household. Therefore, children who are at school living in group quarters are treated as if 
they were members of their parent's households. ${ }^{3}$ As a result, we are able to match $74 \%$ of 18 and 19 year olds to their parent's household and personal characteristics. ${ }^{4}$

Previous work on college entry employs the October supplement to the CPS. We believe that the use of the March supplement is an improvement for two reasons. First, the family intra-relationship variable in the October supplement is virtually non-existent prior to 1984 . While one can determine if a household member is a head, spouse, or dependent, it is impossible to ascertain if a dependent is a family member. It is therefore impossible to determine if a member is a child of the household head. ${ }^{5}$ Second, the background measures in the October supplement, especially income measures, pale in comparison to the March supplement in both quantity and quality (Hauser 1993).

One disadvantage of the March supplement is the absence of an indicator stating if a person received a high school diploma. While the October supplement contains the variable explicitly, the March supplement only reports a person $₹$ highest grade attained. For our purposes, therefore, we treat a person who completed the 12th grade as a high school graduate. Regardless of the differences in the data sets, our results are robust across both the March and October supplements.

\footnotetext{
${ }^{3}$ Hauser (1993) and Kane (1994) use CPS data from the October supplement and make similar assumptions in order to match 18 and 19 year olds with parental and household characteristics. Cameron and Heckman (2001) note the limitations of this sample selection.

${ }^{4}$ Other 18 and 19 year olds are household heads or spouses of a household head $(11.7 \%)$, other family members of a household (6.3\%) or non-family members of a household (8.3\%). By focusing on 18 and 19 year olds, we are not allowing for the possibility that blacks may attend college later than whites. While we cannot test this directly (because of our inability to get family background characteristics for 25 year olds in the CPS), we do look at overall black-white college enrollment patterns for 25 year olds overall and find that they are similar to those of 18/19 year olds.

${ }^{5}$ In fact, a dependent may very well be a sibling or parent of the household head if age distinctions are not carefully noted. In the March CPS, almost $15 \%$ of dependents are not the household head children, which suggests that assigning them as such in the October CPS could affect results.
} 
In this paper, we are examining the college enrollment decisions of 18 and 19 year olds who have completed high school. ${ }^{6}$ Similar to Kane (1994), an individual is considered as enrolled in college if the highest grade attended, prior to 1993, is 13 or higher. As of 1993, individuals are considered enrolled in college if they indicate that they have completed Asome college@or if they indicate that they are currently enrolled in college. ${ }^{7}$

Table 1 presents summary statistics of our sample. Whites are more likely to go to college on average, have higher family income, and have more highly educated mothers. Blacks are more likely to be living in a female-headed household with the mother on welfare. They are also more likely to be living in a central city and in the south. ${ }^{8}$

IV. Black versus White College Enrollment: The Facts

The trend in college enrollment for blacks and whites (Figure 1) is striking. Even more striking is this trend when one controls for family background; examining aggregate trends in college enrollment fails to capture important variation by family background. (Table 2) When we break college enrollment down by this SES and compare blacks to whites, we see that, at low ends of the SES spectrum, blacks are actually more likely to attend college than comparable whites. As we move up the SES spectrum,

\footnotetext{
${ }^{6}$ We focus on enrollment rates for individuals who completed high school. The CPS does not consistently distinguish high school equivalency completers from traditional high school graduates, so we refer to both groups as Aigh school completers.@Most high school equivalency degrees granted in the U.S. are GED degrees, which require no classroom training to obtain. See Cameron and Heckman (1993) for more details.

${ }^{7}$ We compare our results using the March supplement to the same analysis using the October supplement; in the October supplement, this break occurs at 1983 instead of 1992.

${ }^{8}$ We do not analyze Hispanic college-entry in this paper due to sample size limitations and the changing
} 
this relationship twists and, at the top, we can see that blacks are less likely to attend college than their white counterparts.

Table 2 breaks our sample into 3 periods and presents the average black and white college enrollment rates for all 18-19 year old high school graduates. ${ }^{9}$ The first three rows are at the heart of much of the previous literature. We then break the sample even further into SES groups and present the average rate of college enrollment across the SES distribution. Individuals were assigned an SES group based on an initial regression using the pooled sample by year relating college enrollment to family background characteristics ${ }^{10}$. Individuals were then ranked based on their predicted values from this regression; the sample was divided into those in the bottom $20 \%$ of the distribution, the middle $60 \%$, and those in the top 20\%. Table 2 shows that, in the earliest 2 periods, low SES blacks were more likely to attend college than low SES whites; among the middle and high SES groups, college enrollment is relatively equal for blacks and whites. However, in the latest period, the relationship flattens out and blacks are less likely to attend college at all points along the SES spectrum. Table 3 shows the relationship between family background and college enrollment broken out for men and women; again, we see that the patterns hold for both men and women. As a result, in the remainder of the paper we analyze men and women together when studying differences between black and white college

composition of U.S. Hispanics.

${ }^{9}$ The data are broken into 3 periods for ease of exposition; results are similar when broken down into shorter periods.

${ }^{10}$ The index we use to represent SES is, in fact, a measure of the individual's propensity to attend college. This propensity appears to coincide with what we consider to be measures of family background: individuals with lower family incomes and poorer educated parents are less likely to attend college. The probit based on the college enrollment decision merely provides a set of weights for the creation of an index. While these weights are somewhat arbitrary, the results are relatively insensitive to 
enrollment.

Table 4 reveals the same pattern in a regression framework.11 College enrollment is regressed on a number of family characteristics, including mother's education, father's education, welfare status, single parent family indicator, family income (log form), income squared, family size (log form), a sex indicator, center city and rural indicators, and dummies for region of the country. In addition, data is divided into 3 periods (1973-78, 1979-89, 1990-1998), which are included as dummies and interacted with an indicator equal to one if the individual is black. Column 1 presents these results. Consistent with the earlier literature, we see that blacks in the earliest period are more likely to enroll in college once one controls for family background. This effect dissipates over time, until, in the latest period, blacks are less likely to enroll in college, controlling for family background.

The impact of the family background variables on college enrollment is quite consistent with expectations. Better educated parents are associated with a higher probability of the child attending college. Controlling for parents education, family income appears to have a negative impact on college enrollment; this may be due to the idea that a "more successful" (i.e. higher income) less educated parent may suggest to a child that there is no need for education, as is the case with a "less successful" (i.e. lower income) well-educated parent. Finally, consistent with the literature, we find that men are less likely to attend college than women, ceteris paribus (See Anderson, 2001.)

Column 2 then presents the results when the black dummy in each period is interacted with dummies indicating low SES, middle SES, or high SES family backgrounds. Importantly, we see that it is blacks

our choice of SES measure.

11 All standard errors are adjusted for clustering at the state level. 
from low SES backgrounds who are more likely to attend college than their white counterparts; this effect dissipates as one moves up the SES distribution. It is also interesting to note that this impact is strongest in the earliest period; by the middle period the effect is somewhat reduced and it has disappeared by the last period.

It is not surprising that we find that blacks are more likely to attend college at some points during the last 30 years; this finding is consistent throughout the literature. The interesting feature is that low-SES blacks, and not high-SES blacks, are doing better than equivalent whites and thus driving this result. Again, this finding runs counter to the notion that blacks who achieve gains in education attainment tend to be those from high SES backgrounds. Evidence from the 1970s and 1980s directly contradicts the "cream-skimming" argument that well-off blacks are enjoying the benefits of improved education attainment relative to whites.

\section{Explanations}

\section{Data sample selection}

One possible explanation is that these relationships are merely an artifact of our data selection criterion; we are selecting only those 18 and 19 year-olds who are still dependents of their parents and who also completed high school. We confirm our overall findings with the use of both the October CPS and the National Longitudinal Survey of Youth (NLSY), which suggests that sample selection is not driving our results. In addition, as we noted previously, we are able to match over $70 \%$ of individuals to their parents in our sample.

If we delve deeper, we find other reasons to suggest that sample selection is not the primary 
explanation of our findings. We test this hypothesis by comparing individuals who we are able to match to their parents at age 18 and 19 to individuals we are able to match to their parents at age 15 or 16 three years prior. At age 15 or 16, the fraction of children who are not part of their parent's household is much smaller; as a result, we are able to look at the family background characteristics of these younger individuals and compare them to our matched sample three years later. In order to explain the relationships that we observe in the cross-section, it would need to be the case that we are somehow selecting better blacks (or relatively worse whites).

From Appendix Table 1 we can see that individuals in our sample are slightly better than the family background of 15 and 16 year olds three years earlier (this is consistent with the fact that, at age 18 or 19, individuals who have already formed their own household are more likely to come from less advantaged family backgrounds). However, this is relatively consistent for both blacks and whites. In fact, it does not appear that there is much selection of our sample, as the means of the family background variables are relatively similar among the 18/19 year olds and the 15/16 year olds three years earlier.

A second concern is that the pattern we observe may be driven by our decision to focus on high school graduates only. However, restricting our sample to high school graduates does not affect our results; we see the same relationship when we consider college enrollment rates relative to the whole population of 18 and 19 year olds. (See Appendix Table 2.) In addition, when we look at the probability of high school graduation by family background characteristics, we see a similar, although much weaker, relationship, suggesting the using the whole population as a control group would only reinforce our findings. 


\section{Mis-Measurement of Family Background}

When examining the trends in black college enrollment over time, Kane (1994) noted that one part of the story is the improvement in family background characteristics of blacks over this time period. Indeed, the trend is striking; as Figure 3 shows, there have been remarkable improvements in mothers' education--a particularly good predictor of college enrollment--for blacks over this time period. This trend is especially notable among less than high school and high school educated mothers and less pronounced (relative to whites) among more educated women. In much of our analysis we are explicitly controlling for family background characteristics. While these changes are obviously part of the story in explaining what is happening over time, it cannot explain the patterns we observe in the cross section.

Another concern may be that, in the earlier periods, observable family characteristics do a poor job of characterizing the true family background for blacks but do a better job for whites. This could be due to poor labor market and educational opportunities for blacks in the 1940s and 50s, which would make otherwise able individuals choose not to get more education. As a result, although families may appear, based on observables, to have family backgrounds less conducive to higher educational attainment, unobservable parental "quality" among blacks may actually be higher than observable characteristics suggest. As a result, the pattern we see would merely be an artifact of improper classification of blacks. Over time, observable characteristics may become a better measure of family background for blacks, which is why we would observe the cross-section relationship flattening over time.

One observation that refutes this possibility is that we do not see the same pattern when we 
isolate the earliest part of our sample, the late 1960s. If it were really the case that weak measures of family background for blacks caused the cross-sectional relationship we observe in the 1970s and early 80 s, then we would expect to see the same relationship in the 1960s. But we don₹, in fact, we observe the same relationship in the 1960 s as we do in the 1990s.

As another test, we considered the extreme case. If comparing blacks and whites with similar family background characteristics is not a valid comparison, as we have assumed thus far, then what if we compare blacks and whites at the same percentile in their own racial distribution of family background characteristics? This methodology implicitly assumes that blacks and whites have the same underlying distribution of family backgrounds, even though observably blacks look worse. To test this, we run regressions of the probability of college enrollment as a function of observable characteristics separately for blacks and whites and then rank individuals in each group based on their predicted values. We then compare individuals at the different percentiles in each group; that is, we compare the probability of college enrollment for individuals in the $20^{\text {th }}$ percentile of the black distribution to those in the $20^{\text {th }}$ percentile of the white distribution. Table 5 presents the results when we do this; it allows us to compare college enrollment probabilities for the bottom $20 \%$ of the black distribution to the bottom $20 \%$ of the white distribution, the middle part of the two distributions, and then the top $20 \%$ of both distributions. ${ }^{12}$ We can see that the same relationship appears to hold, although it is somewhat weaker. Blacks at the lower end of their SES distribution still do relatively better than those at the upper end

\footnotetext{
${ }^{12}$ Note that in earlier comparisons, the bottom $20 \%$ of the SES distribution was not calculated separately for blacks and whites; as a result, we were comparing individuals with similar observable family background characteristics instead of blacks and whites at the same points in their own distribution.
} 
relative to their white equivalents. The results of this "extreme" case regression offer convincing evidence that low-SES blacks are outperforming their white counterparts. In Table 5, by assuming a similar distribution of characteristics across the races, we are now comparing whites to blacks who are observably much worse (because, on average, blacks have worse family background characteristics than whites especially at the low end of the SES spectrum). We still see low-SES blacks performing the relative best.

\section{Different Costs and Benefits of College Enrollment}

Another explanation is that individuals are behaving optimally, considering costs and benefits, and the observed patterns of behavior reflect responses to different choice sets. When an individual is deciding whether to enroll in college, he/she considers a number of factors. The first is the cost of going to college, both the direct cost in terms of tuition, as well as the indirect cost in terms of the opportunity cost of not working. He also considers the benefit, generally measured as the financial return to going to college. Because these factors can vary across individuals of different socioeconomic status as well as over time, they may be able to explain the pattern we observe in the data. Either blacks face different costs or benefits of going to college, or, facing the same costs and benefits, they respond differently for some reason. We explore whether we see any evidence of this in the data.

The existing literature has already considered the effect of local labor market conditions on college enrollment (See, for example, Rivkin 1995); however, in doing so, they have been limited by a single cross-sectional analysis or have assumed that blacks and whites face the same labor market and therefore include a single measure for blacks and whites (see, for example, Kane 1995). Theory 
suggests that strong labor markets will discourage college attendance, as the opportunity cost is higher. However, in general, the average wage as a measure of the opportunity costs tends to work in the wrong direction, as blacks are more likely to live in cities, which have higher wages. Average local wages and unemployment rates have had little success explaining variation in college enrollment.

As mentioned earlier, there is limited work that has considered the fact that blacks face a different labor market from whites. However, the idea that they face different labor markets is consistent with the evidence presented in Bound and Freeman (1992) showing that, from the mid 1970s through the 1980s, there was a widening in black-white earnings and employment gaps among young men, with the gap in earnings widening particularly among college graduates and in the Midwest and the gap in employment widening most among high school dropouts. Figures 4 and 5 show the distinction between black and white labor market outcomes, specifically unemployment rates and the college premium; this disparity between black and white labor market experiences suggests a need for considering them separately.

Finally, the literature has assumed that individuals from advantaged backgrounds respond similarly to costs and labor market conditions as do individuals from disadvantaged backgrounds. This, however, is an empirical question that we test directly. In particular, earlier evidence has suggested that college costs play an important role in determining college enrollment; however, if college costs have a differential impact based on family background, policies targeted at individuals from disadvantaged backgrounds need to incorporate these differences in order to evaluate the potential impact of the policy.

Table 6 tests these hypotheses by examining the relationship between race-specific local labor 
market variables, college tuition, and college enrollment. We first present results when coefficients on these variables are constrained to be the same for all individuals of the same race, as the earlier literature has done, and then allow the impact to vary by family background.

We include a number of labor market measures in our regression. Ideally, we would like to calculate labor market variables that vary by race, state, and year. Unfortunately, the March CPS does not contain sufficient observations to calculate such labor market variables. As a result, we calculate time-, race-, and state-varying labor market variables using the Outgoing Rotation for the years 19791998. ${ }^{13}$ Because the Outgoing Rotation begins in 1979, we use the March CPS to calculate time-, race-, and region-varying, labor market variables from 1973-1979. The March CPS does not provide consistent state identifiers prior to 1976 ; we use their more aggregate identifier which breaks the country into 21 state groups. ${ }^{14}$

Our first measure of local labor market conditions is the unemployment rate, calculated using individuals 25-40 years of age. We calculate it separately for blacks and whites; if blacks faced higher unemployment rates in the market, possibly due to factors such as discrimination, they may be more likely to go to college than observably equivalent whites.

We also consider the relative return to a college education, measured as the ratio of the average wage for college graduates aged 25-40 to the average wage for high school graduates for the same age

\footnotetext{
${ }^{13}$ Local labor market variables constructed using the Outgoing Rotation are 3 year moving averages. ${ }^{14}$ All state-level data was aggregated to the state-group level by averaging across individuals in the states, thereby giving more weight to larger states. From here on in the paper, when we refer to states we are actually referring to state-groups.
} 
group among full time workers. ${ }^{15}$ Again, we calculate a race-specific measure, allowing for different returns for blacks and whites in a particular state.

As a measure of college costs, we utilize resident university tuition data from the State of Washington Higher Education Coordinating Board. These data vary by state and by year for the years in our sample. To calculate the appropriate "state-group" tuition, we use a weighted average of state tuitions within the group, with weights given by the respective state population for the given year.

Table 6 presents the results when we estimate probit models of college enrollment for blacks and whites separately. Only the coefficients on the labor market and tuition variables are shown; however, the regressions all include the family background, regional, and center city/rural variables presented in Table 4.

Columns 1 and 3 present the basic results when one includes tuition and local labor market variables in a college enrollment regression. While whites appear to respond as expected to both labor market and tuition variables, this is not true for blacks; in fact, these variables do little to explain what is happening with black college enrollment. ${ }^{16}$ Among whites, Column 1 shows that a higher college premium increases college enrollment, as does a higher unemployment rate and lower tuition (although at a decreasing rate as tuition rises). In columns 2 and 4 , we allow for differential impacts of these variables by family background category. In the case of both blacks and whites, tuition appears to have a significant impact on college enrollment among low-SES individuals. However, this effect disappears among higher SES blacks, while it holds true among whites of all SES groups. Notably, whites respond

\footnotetext{
${ }^{15} \mathrm{~A}$ full-time worker is defined as one who worked at least 35 hours the previous week. 16 Note that Kane (1994) finds a significant impact of tuition on college enrollment. This result appears
} 
strongly to labor market variables, with high SES whites responding even more strongly to the college premium than lower SES whites. On the contrary, blacks appear to respond negatively to the college premium. This reflects in large part the fact that blacks appear to respond perversely to the high school wage — as high school wages deteriorated during the late 1970s and early 1980s, it appears that blacks did not respond by enrolling in college, as would be expected. Low SES blacks responded to increasing tuition costs by reducing college attendance, while at the same time low SES blacks did not respond to labor market factors that should encourage college enrollment. To understand the magnitude of their responsiveness, within the relevant range, an increase in tuition of approximately $5 \%$ reduces college enrollment of low SES blacks by almost $35 \%$.

These results suggest some important patterns. Among whites, tuition costs and local labor markets appear to have a significant impact on their college enrollment decisions (and these effects are even stronger among high SES individuals). On the contrary, blacks appear to be relatively insensitive (or even responding in a way that is negatively related) to local labor market conditions. Tuition appears to be the only policy variable that has a strong impact on blacks, and only those from poorer family backgrounds.

How much of the variation in enrollment among blacks and whites do these variables explain? Figure 6 presents white college enrollment, black college enrollment, and predicted college enrollment for blacks if they had white characteristics and faced white tuition costs and labor market conditions. (i.e. using black coefficients from table 6 column 4). We can see that, although family background, local labor market characteristics, and tuition costs can explain much of the differences between black and 
white college enrollment in the later period, it actually overpredicts black college enrollment in the earlier period.

Although we explain little of the overall variation, the results have important policy implications. Earlier work that suggested that college tuition has an important impact on college enrollment behavior did not consider different responses by individuals from diverse family backgrounds. However, empirical evidence suggests that there may be diverse responses. As a result, efforts targeted at improving college enrollment among disadvantaged individuals must consider the appropriate relationship when evaluating different policies.

\section{Other Possible Explanations}

\section{Affirmative Action}

Anecdotal evidence suggests that affirmative action may be an explanation for the patterns we observe. Clearly, if we knew nothing beyond the positive coefficient on the black dummy in the college enrollment equation, this would seem like a reasonable explanation. In addition, the time series seems roughly consistent with affirmative action: increasing strength in the late 1970s and then declining in the 1980s.

However, when we examine more closely, we see a number of contradictions. First, if there is affirmative action in hiring and wages/promotion, then we would expect our race-varying labor market measures to reflect this; black workers would have lower unemployment rates or higher wages as a result.

If there were affirmative action in college admission, we would expect this to affect blacks 
across the SES spectrum and would thereby observe a level shift up of black enrollment instead of the pattern we observe, with low-SES blacks more likely and high-SES blacks less likely to attend college than equivalent whites. In addition, anecdotal evidence also suggests that colleges most likely to admit based on affirmative action would be those who would attempt to Arream-skim@he best black students; in this case, we would expect the opposite pattern from the cross-section we observe.

Directly testing the effects of affirmative action is difficult, however, because of the difficulty in measuring differences in the "effectiveness" of affirmative action in different states at different times. We can, however, compare the patterns we observe in two year- versus four year-colleges. Because many two year colleges have open enrollment, we would not expect to see the same relationship in two-year as in four-year college enrollment if affirmative action is the underlying cause. When we estimate a multinomial logit where the potential outcomes are no college enrollment, two-year college enrollment, and four-year college enrollment (Table 7), we see similar relationships for both types of college enrollment. In the earliest period, the lowest SES blacks are more likely to attend college than the equivalent whites for both two- and four-year colleges. In the middle period, this relationship persists among four year college enrollees but dissipates among the two-year college students. Finally, in the third period, this relationship has disappeared among all students, and blacks are unambiguously less likely to attend either type of college than equivalent whites. These results suggest that it is not affirmative action among the four-year colleges that is driving the relationship. ${ }^{17}$

\footnotetext{
${ }^{17} \mathrm{We}$ use the October CPS for this estimation because the March does not distinguish between enrollment in two-year and four-year colleges. It is interesting to note that, over this time period, the percentage of blacks attending two year colleges as a fraction of total blacks attending college is remaining relatively constant, as is this number for whites.
} 


\section{Credit Constraints/Pell Grants}

There is also a literature that considers the effect of credit constraints on college enrollment decisions. If blacks face different credit constraints than whites, then one might expect to see different patterns of college enrollment by race. Cameron and Heckman (2001) examine this directly to determine whether differences in college enrollment by race are due to differences in family background or differences in the availability of credit. The authors conclude that it is family background, and not credit constraints, that explain the relationship between family characteristics and school attendance. In contrast, Acemoglu and Pischke (2001) exploit changes in the distribution of family income to examine the effect of parental resources on college education and find evidence of large effects of family income on college enrollment.

In the CPS, we do not observe wealth, so it is difficult to test this directly. Our findings on this topic are mixed, however. Though the cross-section pattern we observe runs counter to traditional belief that poorer blacks are more credit constrained than equivalent whites, the fact that we find that tuition has such a strong impact on low SES blacks (and not blacks from wealthier backgrounds) may provide some support for the credit constraint argument. ${ }^{18}$

\section{Pell Grants}

\footnotetext{
${ }^{18}$ Another proposed explanation is differences in school quality by race. However, to observe the relationship we see, it would have to be the case that poorer Blacks, who receive lower quality education, are compensating by increasing the quantity. This runs counter to much of the evidence on the relationship between school quality and quantity, which suggests a positive relationship
} 
Finally, Kane (1994) also considers the roll of financial aid in the form of Pell grants and finds little effect of changes in Pell grants on college enrollment. More specifically, he looks at the establishment of Pell grant awards and compares changes in college enrollment for eligible versus ineligible youths before and after the implementation of the program. He concludes that there is little evidence that those to whom the Pell grant program was targeted enjoyed particularly large increases in enrollment.

It is unlikely that changes in Pell grant generosity are driving the relationships we observe in the data. Given that Pell grants are not race-specific but instead are income specific, we should not expect to see differential effects of Pell grants within SES class; low-income individuals should benefit equally regardless of race. Additionally, we see similar results when we allow year*SES effects, which should pick up any changes in the generosity of Pell Grants for low-SES individuals.

However, it may be the case that there are wealth differences among low-SES blacks and whites that we are unable to pick up in our dataset. Because we observe differential behavior by SES and race, this could be consistent with some sort of financial aid/credit constrain story. Further work needs to address this issue, focusing on the differential impact by family background.19

\section{Conclusion}

Although it is well-documented in the literature that, controlling for family background

between the two. (See Light and Strayer, 2000).

19 Consistent with the findings in this paper, recent work by Linsenmeier, Rosen, and Rouse (2002) finds differential effects of financial aid packages on low-income blacks and whites when they focus on one university. 
characteristics, blacks are more likely to attend college than whites, very little work has focused on explaining this phenomenon. The literature instead has primarily focused on understanding the time series patterns of black college enrollment.

This paper attempts to understand what is driving this difference between black and white college enrollment. Interestingly, it is not the blacks at the high end of the family background spectrum who are more likely to attend college than their white counterparts; it is the blacks at the bottom of the SES spectrum who are driving this result. In addition, this relationship appears to flatten over time; by the 1990s, blacks at all parts of the SES spectrum are less likely to attend college than equivalent whites.

We examine possible explanations for this phenomenon and make a number of conclusions. First, contrary to earlier evidence, college tuition appears to explain very little of the observed pattern. Interestingly, we do uncover differential responses by individuals from different family backgrounds. As a result, although we explain little of the overall variation in college enrollment, the results have important policy implications. Earlier work that suggested that college tuition has an important impact on college enrollment behavior did not consider different responses by individuals from diverse family backgrounds. However, the empirical evidence suggests that there may be diverse responses. In particular, low-income blacks appear to be very sensitive to changes in tuition costs, while blacks from middle- or high- SES backgrounds are not. As a result, efforts targeted at improving college enrollment among disadvantaged individuals must consider the appropriate relationship when evaluating different policies.

While this paper has focused on differences between blacks and whites, these findings suggest 
the need for more extensive research when considering policies directed at the assimilation of more disadvantaged groups into the education system, and future research will extend this analysis to immigrants. It is not surprising that appropriate education policies vary for by race for different target groups. This research suggests that these policies must also take into account different behavioral responses based on family background characteristics as well. 
References

Bound, John, and Richard B. Freeman (1992). AWhat Went Wrong? The Erosion of Relative Earnings and Employment among Young Black Men in the 1980s.@i Que Quarterly Journal of Economics 107 (1): 201-32.

Cameron, Stephen V., and James J. Heckman (2001). AThe Dynamics of Educational Attainment for Black, Hispanic and White Males,@ournal of Political Economy, forthcoming. (1998). ALife Cycle Schooling and Dynamic Selection Bias: Models and Evidence for Five Cohorts of American Males@ Journal-of-Political-Economy, 106(2), April.

------- (1993). AThe Nonequivalence of High School Equivalents,@Journal of Labor Economics, 11(1), January: 1-47.

Catsiapis, George (1987). AA Model of Educational Investment Decisions. @he Review of Economics and Statistics 69.1: 33-41.

Constantine, Jill M., and Laura Perna. AWhy Do So Many More Black Women than Black Men Enroll in College?@inpublished manuscript.

Hauser, Robert M (1993). ATrends in College Entry among Whites, Blacks, and Hispanics.@Studies of Supply and Demand in Higher Education: A National Bureau of Economic Research Project Report. Eds. Charles T. Clotfelter and Michael Rothschild. Chicago and London: University of Chicago Press: 61-104.

Kane, Thomas J (1994). ACollege Entry by Blacks since 1970: The Role of College Costs, Family Background, and the Returns to Education.@ournal of Political Economy 102(5): 878-911.

Fuller, Winship C., Charles F. Manski, and David A. Wise (1982). ANew Evidence on the Economic Determinants of Postsecondary Schooling Choices, @ournal of Human Resources, 17(4), Fall: 477-98.

Linsenmeier, David M., Harvey S. Rosen, and Cecilia Elena Rouse (2002). "Financial Aid Packages and College Enrollment Decisions: An Econometric Case Study." NBER Working Paper No. 9228.

Pischke, J. S., and Daron Acemoglu (2001). "Changes in the Wage Structure, Family Income, and Children's Education.” European Economic Review, 45: 890-904. 
Rivkin, Steven G (1995). ABlack/White Differences in Schooling and Employment.@rhe Journal of Human Resources 30(4): 826-52.

Strayer, Wayne (2000). AThe Returns to School Quality: College Choice and Earnings.@unpublished manuscript. 
Table 1

Summary Statistics

(March CPS Data 1968-1998)

\begin{tabular}{|c|c|c|c|c|}
\hline & \multicolumn{2}{|c|}{ Whites } & \multicolumn{2}{|c|}{ Blacks } \\
\hline & Mean & St Dev & Mean & St Dev \\
\hline College Entry & 0.66 & 0.47 & 0.58 & 0.49 \\
\hline Age & 18.6 & 0.49 & 18.6 & 0.49 \\
\hline Sex $($ Male=1 $)$ & 0.49 & 0.50 & 0.42 & 0.49 \\
\hline Unemployed & 0.07 & 0.25 & 0.16 & 0.37 \\
\hline Working & 0.58 & 0.49 & 0.37 & 0.48 \\
\hline Not in Labor Force & 0.35 & 0.48 & 0.47 & 0.50 \\
\hline Income & 4,686 & 5,537 & 2,820 & 4,650 \\
\hline Family Income & 53,562 & 37,245 & 35,441 & 26,947 \\
\hline \# in Household & 4.5 & 1.5 & 5.0 & 2.0 \\
\hline Single Mother & 0.12 & 0.33 & 0.41 & 0.49 \\
\hline Mother Education & 12.8 & 2.2 & 12.0 & 2.6 \\
\hline Mother on Welfare & 0.008 & 0.09 & 0.08 & 0.26 \\
\hline Father Education & 13.2 & 2.9 & 11.4 & 3.3 \\
\hline Live in City & 0.16 & 0.36 & 0.48 & 0.50 \\
\hline Live in Rural & 0.28 & 0.45 & 0.21 & 0.41 \\
\hline Live in East & 0.34 & 0.47 & 0.30 & 0.46 \\
\hline Live in Midwest & 0.30 & 0.46 & 0.19 & 0.39 \\
\hline Live in South & 0.16 & 0.37 & 0.37 & 0.48 \\
\hline Live in West & 0.21 & 0.40 & 0.14 & 0.35 \\
\hline Tuition & 1,826 & 696 & 1,779 & 714 \\
\hline Unemployment Rate & .05 & .015 & .06 & .029 \\
\hline College Premium & 1.33 & 0.22 & 1.39 & 0.20 \\
\hline $\mathrm{N}$ & & & & \\
\hline
\end{tabular}


Table 2

Average College Enrollment Rates for High School Graduates

by SES Category and Period

\author{
Whites Blacks
}

\title{
Total
}

1973-1978

.61

.56

1979-1989

.64

.57

$1990-1998$

.74

.59

Period 1: 1973-1978

Bottom 20\%

$.45^{*}$

Middle 60\%

.60

.61

Top $20 \%$

.89

.91

Period 2: 1979-1989

Bottom 20\%

Middle $60 \%$

.64

.64

Top $20 \%$

.91

.89

\section{Period 3: 1990-1998}

Bottom 20\%*

Middle $60 \%$

Top 20\%
.46

.75

.93
$.38 *$

$.68 *$

$.88 *$

Source: March CPS. Individuals were divided into SES categories based on a predicted values from a regression relating college enrollment to family background characteristics by year using the pooled sample of blacks and whites. * indicates statistical difference between black and white averages at the $5 \%$ level. 
Table 3

College Enrollment Rates for High School Graduates

by SES Category and Period

Men and Women

\begin{tabular}{lllll}
\hline \multicolumn{3}{c}{ Men } & \multicolumn{2}{c}{ Women } \\
Whites & & Blacks & Whites & Blacks \\
\hline
\end{tabular}

Period 1: 1973-1978

$\begin{array}{lrrrr}\text { Bottom } 20 \% & .31 & .41 & .31 & .48 \\ \text { Middle } 60 \% & .60 & .54 & .59 & .66 \\ \text { Top } 20 \% & .90 & .89 & .88 & .92\end{array}$

Period 2: 1979-1989

$\begin{array}{lllll}\text { Bottom } 20 \% & .35 & .38 & .38 & .44 \\ \text { Middle } 60 \% & .63 & .62 & .66 & .65 \\ \text { Top } 20 \% & .90 & .88 & .91 & .90\end{array}$

\section{Period 3: 1990-1998}

\begin{tabular}{lcccc} 
Bottom $20 \%$ & .44 & .38 & .50 & .39 \\
Middle $60 \%$ & .74 & .68 & .76 & .69 \\
Top $20 \%$ & .93 & .92 & .94 & .87 \\
\hline
\end{tabular}

Source: March CPS. Individuals were divided into SES categories based on a predicted values from a regression relating college enrollment to family background characteristics by year using the pooled sample of blacks and whites. 
Table 4

College Enrollment for High School Graduates: Probit Results

(Standard Errors in Parenthesis)

Coefficients Reflect Partial Derivatives

Dependent variable:

(1)

(2)

College Enrollment

\section{Racial Differences}

Period 1: 1973-1978

Black

$.14 * *$

$.17 * *$

(.01)

(.02)

Black*Mid SES

$-.09 * *$

(.04)

Black*High SES

$-.08$

(.07)

Period 2: 1979-1989

Black

$.09 * *$

$.12 * *$

(.01)

Black*Mid SES

$-.07 * *$

Black*High SES

$-.11$

(.07)

Period 3: 1990-1998

Black

$-.06 * *$

$-.06 * *$

(.02)

Black*Mid SES

.001

(.03)

Black*High SES

$-.05$

(.06)

Source: March CPS. All standard errors are adjusted for clustering at the state level. 
Table 4 (Continued)

\section{College Enrollment for High School Graduates: Probit Results}

(Standard Errors in Parenthesis)

Coefficients Reflect Partial Derivatives

\begin{tabular}{|c|c|c|}
\hline $\begin{array}{l}\text { Dependent variable: } \\
\text { College Enrollment }\end{array}$ & $(1)$ & $(2)$ \\
\hline \multicolumn{3}{|c|}{ Family Background } \\
\hline Mother F Education & & \\
\hline High School Graduate & $\begin{array}{l}.13 * * \\
(.01)\end{array}$ & $\begin{array}{l}.10^{* *} \\
(.01)\end{array}$ \\
\hline Some College & $\begin{array}{l}.25^{* *} \\
(.01)\end{array}$ & $\begin{array}{l}.21 * * \\
(.01)\end{array}$ \\
\hline College or More & $\begin{array}{l}.30 * * \\
(.01)\end{array}$ & $\begin{array}{l}.27 * * \\
(.01)\end{array}$ \\
\hline \multicolumn{3}{|l|}{ Father E Education } \\
\hline High School Graduate & $\begin{array}{l}.10^{* *} \\
(.01)\end{array}$ & $\begin{array}{l}.07 * * \\
(.01)\end{array}$ \\
\hline Some College & $\begin{array}{l}.19 * * \\
(.01)\end{array}$ & $\begin{array}{l}.16^{* *} \\
(.01)\end{array}$ \\
\hline College or More & $\begin{array}{l}.29 * * \\
(.01)\end{array}$ & $\begin{array}{l}.25^{* *} \\
(.01)\end{array}$ \\
\hline On Welfare & $\begin{array}{c}-.12 * * \\
(.02)\end{array}$ & $\begin{array}{c}-.11 * * \\
(.02)\end{array}$ \\
\hline $\log$ (Family Income) & $\begin{array}{l}-.02 * * \\
(.003)\end{array}$ & $\begin{array}{l}-.01 * * \\
(.003)\end{array}$ \\
\hline $\log$ (Family Income $) 2$ & $\begin{array}{l}.004 * * \\
(.001)\end{array}$ & $\begin{array}{l}.004 * * \\
(.001)\end{array}$ \\
\hline $\log ($ Family Size $)$ & $\begin{array}{c}-.08 * * \\
(.01)\end{array}$ & $\begin{array}{c}-.07 * * \\
(.01)\end{array}$ \\
\hline Male & $\begin{array}{c}-.08 * * \\
(.01)\end{array}$ & $\begin{array}{c}-.06 * * \\
(.01)\end{array}$ \\
\hline Center City & $\begin{array}{c}.01 \\
(.01)\end{array}$ & $\begin{array}{c}.01 \\
(.01)\end{array}$ \\
\hline Rural & $\begin{array}{c}-.02 \\
(.012)\end{array}$ & $\begin{array}{l}-.01 \\
(.01)\end{array}$ \\
\hline Midwest & $\begin{array}{l}-.02 \\
(.02)\end{array}$ & $\begin{array}{l}-.01 \\
(.02)\end{array}$ \\
\hline South & $\begin{array}{l}-.01 \\
(.03)\end{array}$ & $\begin{array}{l}-.01 \\
(.02)\end{array}$ \\
\hline West & $\begin{array}{l}-.04 * \\
(.03) \\
\end{array}$ & $\begin{array}{c}-.04 \\
(.024) \\
\end{array}$ \\
\hline $\mathrm{N}$ & 48,634 & 48,634 \\
\hline Pseudo R2 & .1364 & .1384 \\
\hline
\end{tabular}

Regression also includes period indicators, SES indicators, an indicator if the individual is 19 years old, and an indicator if the individual grew up in a single parent household. All standard errors are adjusted for clustering at the state level. 
Table 5

Average College Enrollment Rates for High School Graduates

by SES Category and Period

Race-Specific SES Distribution

Whites Blacks

\section{Period 1: 1973-1978}

Bottom 20\%

Middle $60 \%$

Top $20 \%$

Period 2: 1979-1989

Bottom 20\%

Middle $60 \%$

Top $20 \%$

\section{Period 3: 1990-1998}

Bottom 20\%

.46

Middle $60 \%$

Top $20 \%$
.32

.60

.87

.36

.65

.89
.29

$.55^{*}$

$.74 *$

Black and white SES distributions are determined separately based on race- and year-specific regressions relating college enrollment to family background characteristics. Black individuals were ranked based on the predicted values from their own regression and then compared to individuals in the same percentile of the white distribution. * indicates statistical difference between black and white averages at the $5 \%$ level. 


\section{Table 6}

\section{College Enrollment for High School Graduates \\ Probit Results \\ Standard Errors in Parentheses \\ Coefficients Represent Partial Derivatives}

\begin{tabular}{|c|c|c|c|c|}
\hline \multirow{3}{*}{ College Premium } & \multicolumn{2}{|c|}{ Whites } & \multicolumn{2}{|c|}{ Blacks } \\
\hline & $.20 * *$ & $.14 * *$ & -.12 & $-.21 *$ \\
\hline & $(.07)$ & $(.07)$ & $(.11)$ & $(.12)$ \\
\hline \multirow{2}{*}{ College Premium *Mid SES } & & .04 & & .12 \\
\hline & & $(.05)$ & & $(.10)$ \\
\hline \multirow{2}{*}{ College Premium *High SES } & & $.07 *$ & & .20 \\
\hline & & $(.04)$ & & $(.17)$ \\
\hline \multirow{2}{*}{ Unemployment Rate } & $.93 * *$ & $1.3^{* *}$ & -.31 & -.21 \\
\hline & $(.35)$ & $(.61)$ & $(.95)$ & $(1.05)$ \\
\hline \multirow{2}{*}{ Unemployment Rate*Mid SES } & & -.49 & & -.14 \\
\hline & & $(.59)$ & & $(.59)$ \\
\hline \multirow{2}{*}{ Unemployment Rate*High SES } & & -.52 & & -.20 \\
\hline & & $(.63)$ & & $(1.20)$ \\
\hline \multirow{2}{*}{ Log(Tuition) } & $-.78 * *$ & $-.77 *$ & -.99 & $-2.2 * *$ \\
\hline & $(.32)$ & $(.45)$ & $(.65)$ & $(.64)$ \\
\hline \multirow{2}{*}{ Tuition*Mid SES } & & .08 & & $2.02 * *$ \\
\hline & & $(.47)$ & & $(.69)$ \\
\hline \multirow{2}{*}{ Tuition*High SES } & & .50 & & 2.25 \\
\hline & & $(.44)$ & & $(1.51)$ \\
\hline \multirow{2}{*}{ Log(Tuition) Squared } & $.05^{* *}$ & $.05^{*}$ & .07 & $.16^{* *}$ \\
\hline & $(.02)$ & $(.03)$ & $(.05)$ & $(.04)$ \\
\hline \multirow{2}{*}{ Tuition*Mid SES } & & -.01 & & $-.13 * *$ \\
\hline & & $(.03)$ & & $(.05)$ \\
\hline \multirow{2}{*}{ Tuition*High SES } & & -.04 & & -.15 \\
\hline & & $(.03)$ & & $(.10)$ \\
\hline $\mathrm{N}$ & 43,768 & 43,768 & 4,851 & 4,851 \\
\hline Pseudo R2 & .1484 & .1500 & .0989 & .1182 \\
\hline
\end{tabular}

Regressions also include mother子 education, fatherfeducation, welfare status, $\log$ (family income) and its squared term,

$\log ($ family size), sex, region, central city, and rural indicators. All standard errors are adjusted for clustering at the state level. 


\section{Table 7}

\section{Multinomial Logit of College Enrollment of High School Graduates \\ 2-Year Versus 4-Year Colleges \\ (Standard Errors in Parentheses)}

Period 1: 1973-1978

Black

Black*High SES

Period 2: 1979-1989

Black

Black*Mid SES

Black*High SES
4 Year College
2 Year College

$.23 *$

$.28 * *$

(.13)

$(.11)$

$-.26$

$-.11$

(.16)

$-1.2 * *$

$-.19$

(.41)

$-.12$

$.16^{* *}$

(.10)

$-.23 *$

$-.28 * *$

(.12)

(.10)

.04

$-.51 * *$

(.25)

Period 3: 1990-1998

Black

$-.42 * *$

$-.30 * *$

(.14)

(.12)

Black*Mid SES

.13

.18

Black*High SES

$-.03$

$-.47 * *$

(.32)

Source: October CPS. These results represent partial results from a multinomial logit, run separately by period, with three outcome possibilities: no college, two-year college, and four-year college enrollment. Other variables included in the regression include mothers education (four categories), father's education (four categories), log of family income, log of family size, an age dummy indicating if the individual is 18 , inner city/rural indicators, region indicators, sex, an indicator if the individual is part of a single parent household, and year dummies. Level effects of all interactions are included. SES distributions are determined based on predicted values from year-specific regressions relating college enrollment to family background characteristics. All standard errors are adjusted for clustering at the state level. 


\section{Appendix Table 1 \\ Test of Match Selectivity \\ Family Background Characteristics of Matched 18/19 Year Olds (1973-1998) \\ versus Matched 15/16 Year Olds (1970-1995)}

\section{Whites \\ Blacks}

15/16 Year Olds $\quad$ 18/19 Year Olds $\quad$ 15/16 Year Olds $\quad$ 18/19 Year Olds

Mother Education

High School Graduate .46

.44

.33

.32

Some College

.16

.16

.12

College or More

.12

.11

.05

Father Education

High School Graduate .32

.31

.16

.16

Some College

.14

.13

.06

.07

College or More

.18

.04

.04

Single Parent Household

.15

.17

.48

.51

On Welfare

.02

.22

.18

Family Income

53,575

43,362

28,150

24,715

Household Size

6.2

4.1

6.5

4.9

Male

.51

.49

.49

.47

.16

.17

.51

.50

Center City

Rural

Midwest

.30

.29

.20

.19

South

.18

.18

.40

.38

West

.24

.13

.13

\section{N}

107,203

90,342

17,917

14,380

Source: March CPS. 


\section{Appendix Table 2 \\ College Enrollment Rates \\ by SES Category and Period \\ Without Conditioning on High School Graduation}

Whites Blacks

Period 1: 1973-1978

Bottom 20\%

.18

.24

Middle $60 \%$

.50

Top $20 \%$

.85

.86

Period 2: 1979-1989

Bottom 20\%

Middle $60 \%$

Top $20 \%$

\section{Period 3: 1990-1998}

Bottom 20\%

Middle $60 \%$

Top $20 \%$

.92

.89

Source: March CPS. Individuals were divided into SES categories based on a predicted values from a regression relating college enrollment to family background characteristics by year using the pooled sample of blacks and whites. 
Figure 1: College Enrollment Rates Among High School Graduates By Race

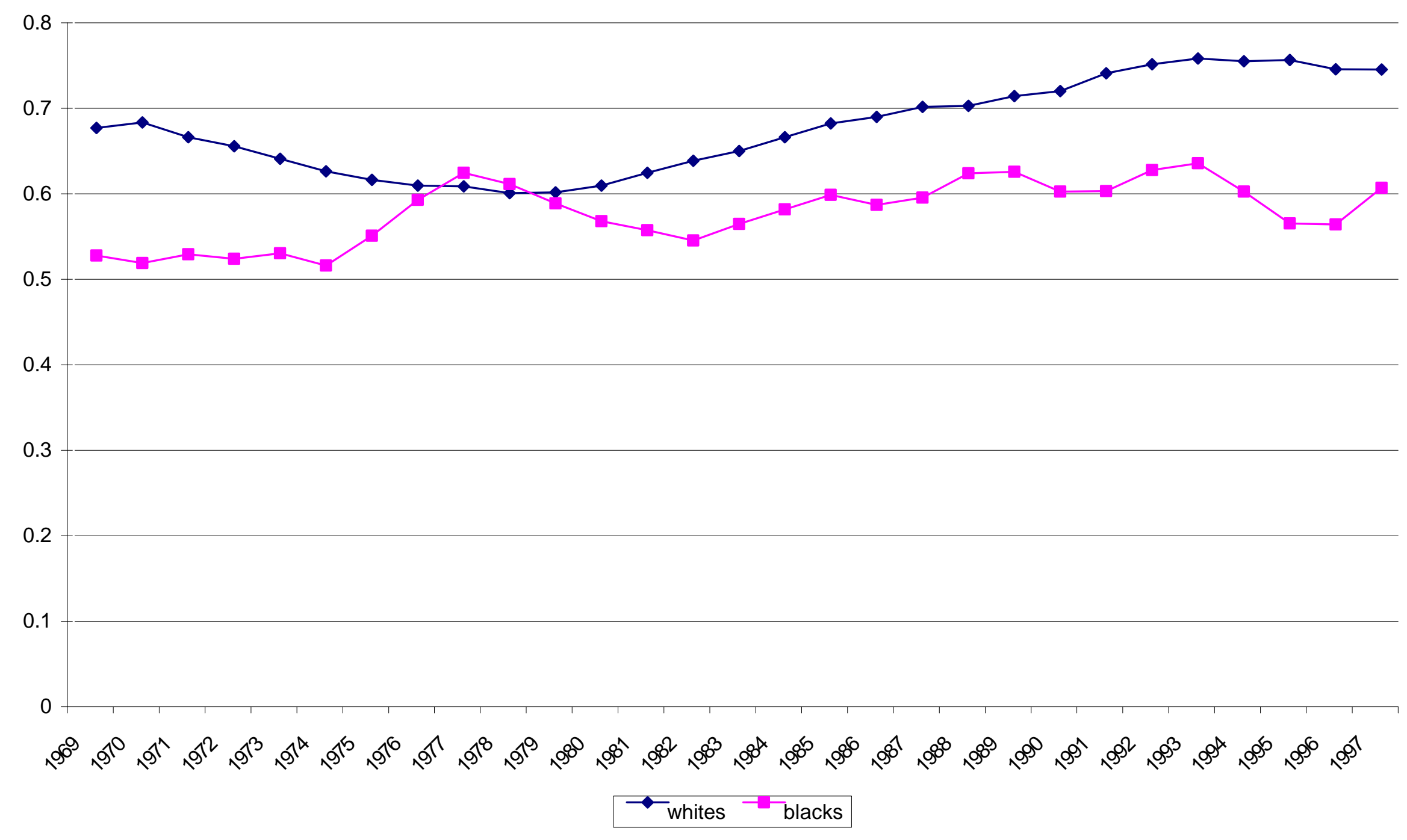


Figure 2: College Enrollment of High School Graduates

By Race and Family Background

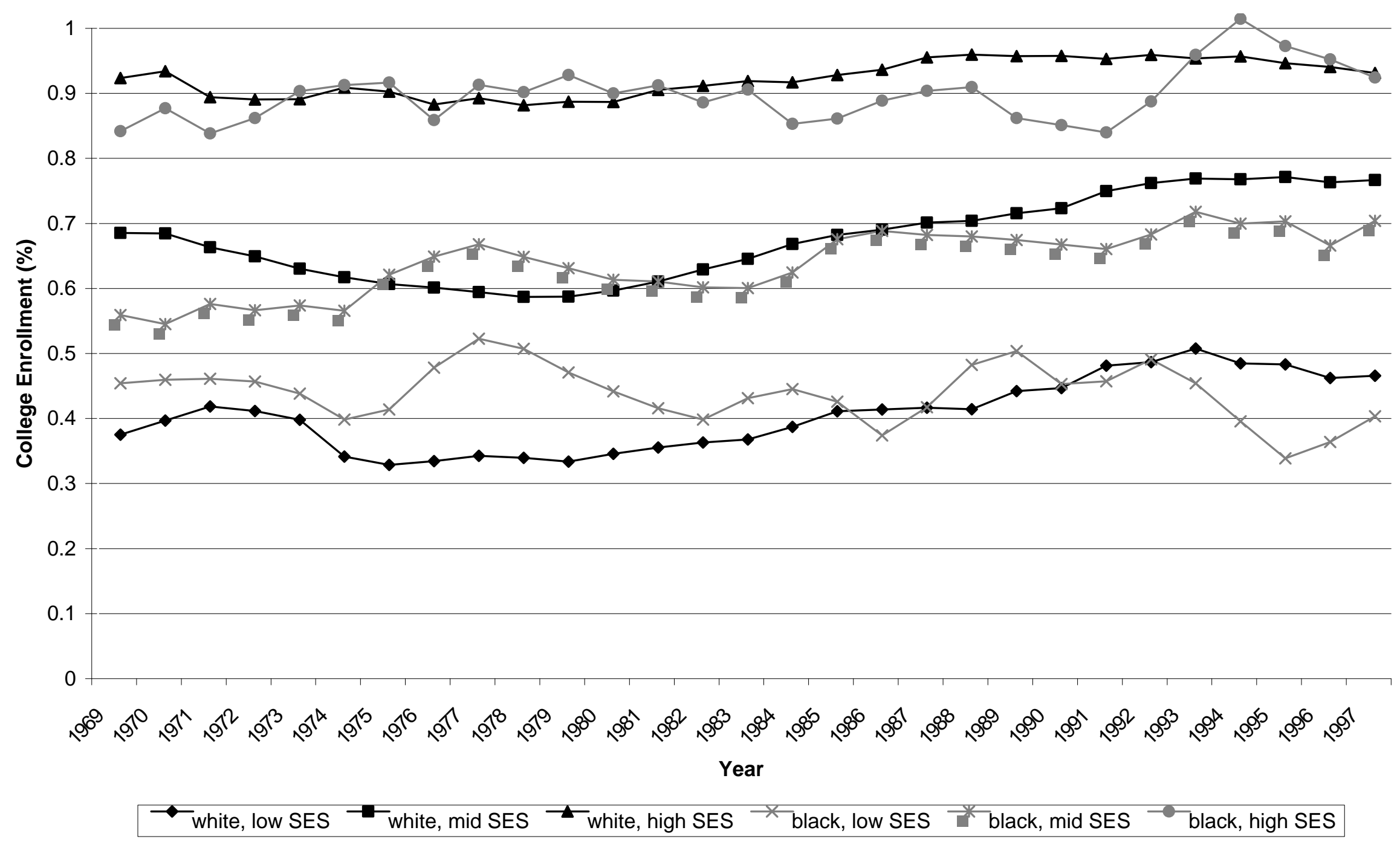




\section{Figure 3}

\section{Percentage of Sample with Less than High School Educated Mothers}

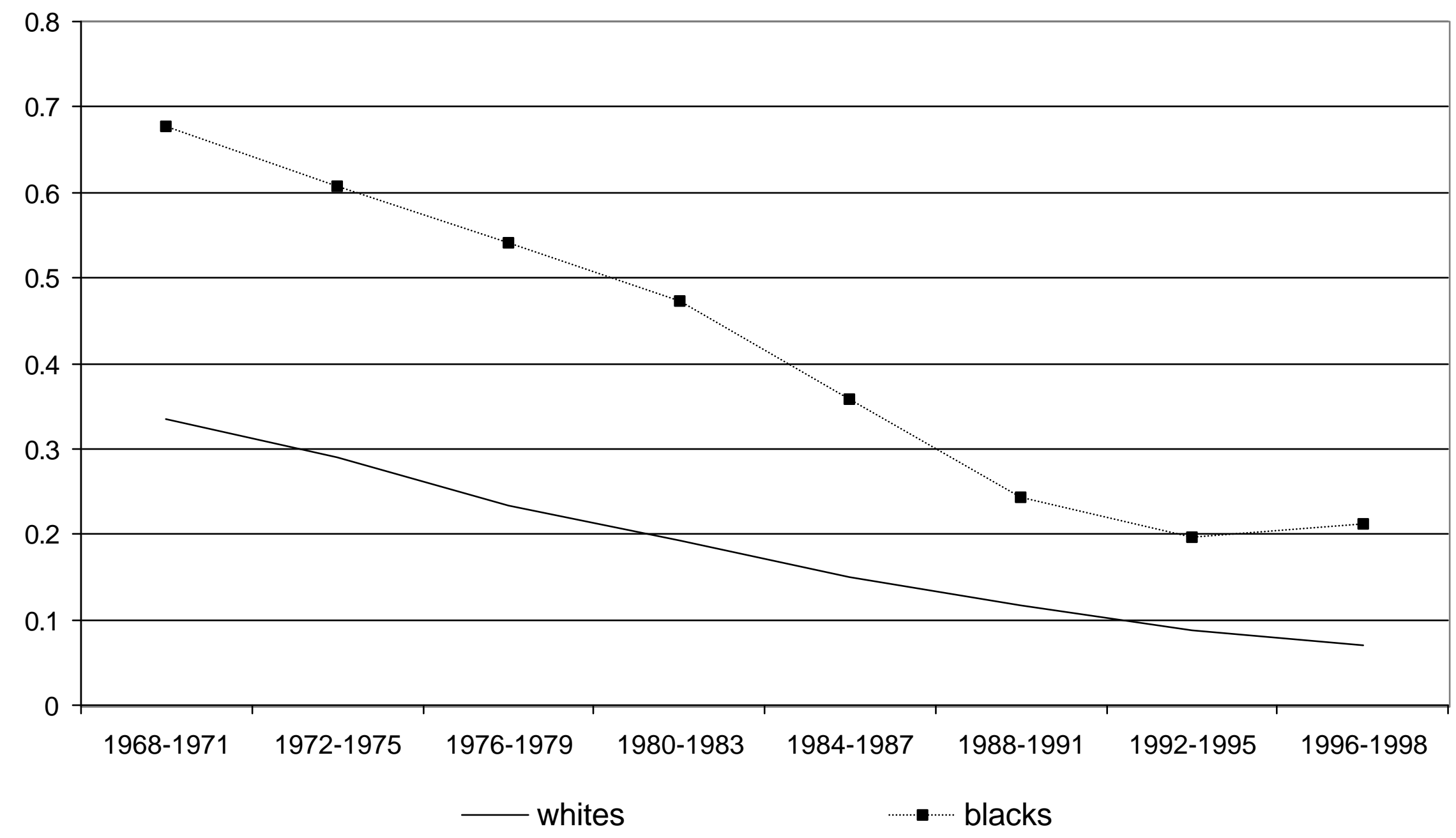

*Authors' calculations using March CPS 


\section{Figure 4}

Unemployment Rate Among Workers with High School Diploma or More

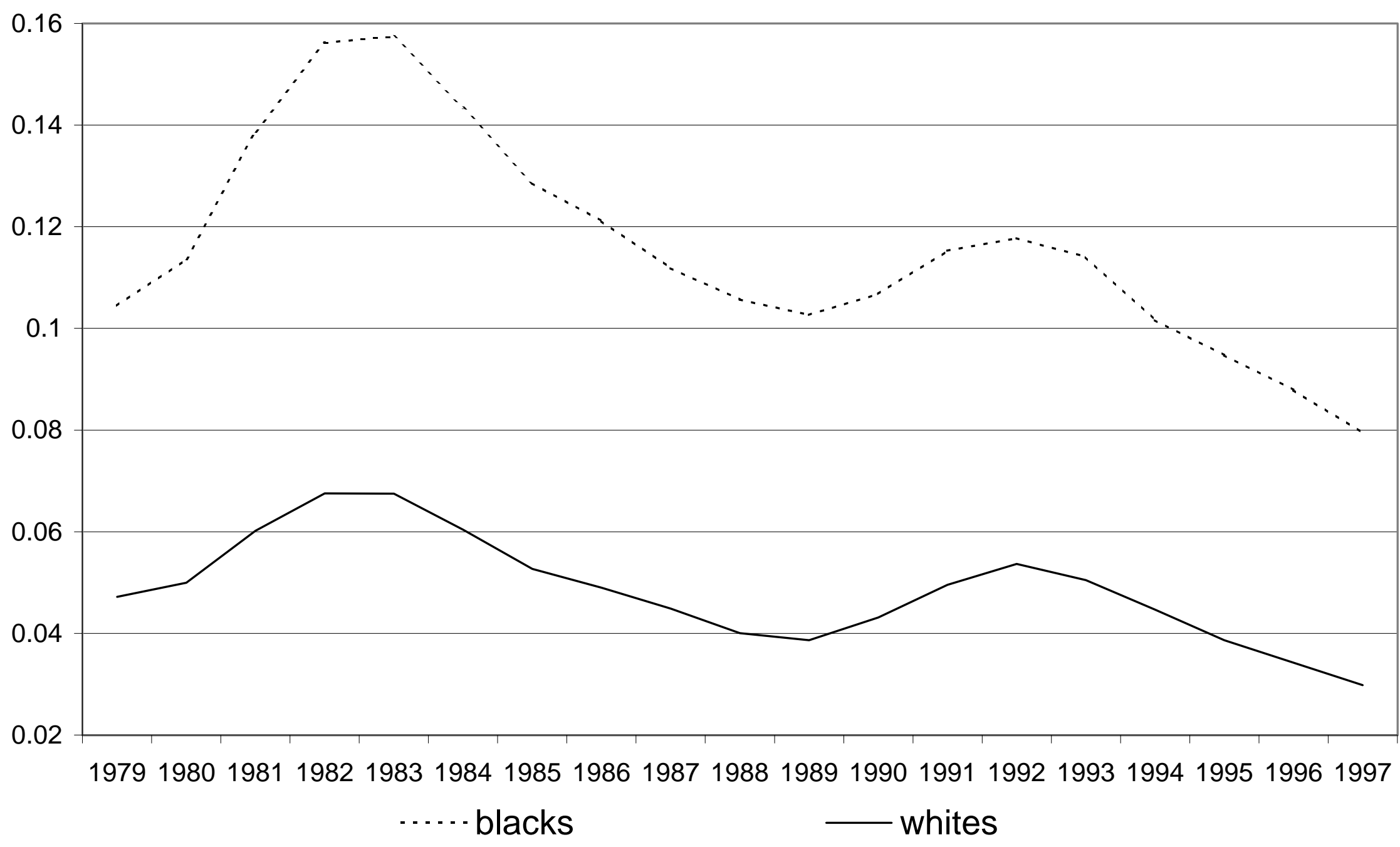

Source: Outgoing rotations group and authors' calculations 
Figure 5

College Wage Premium

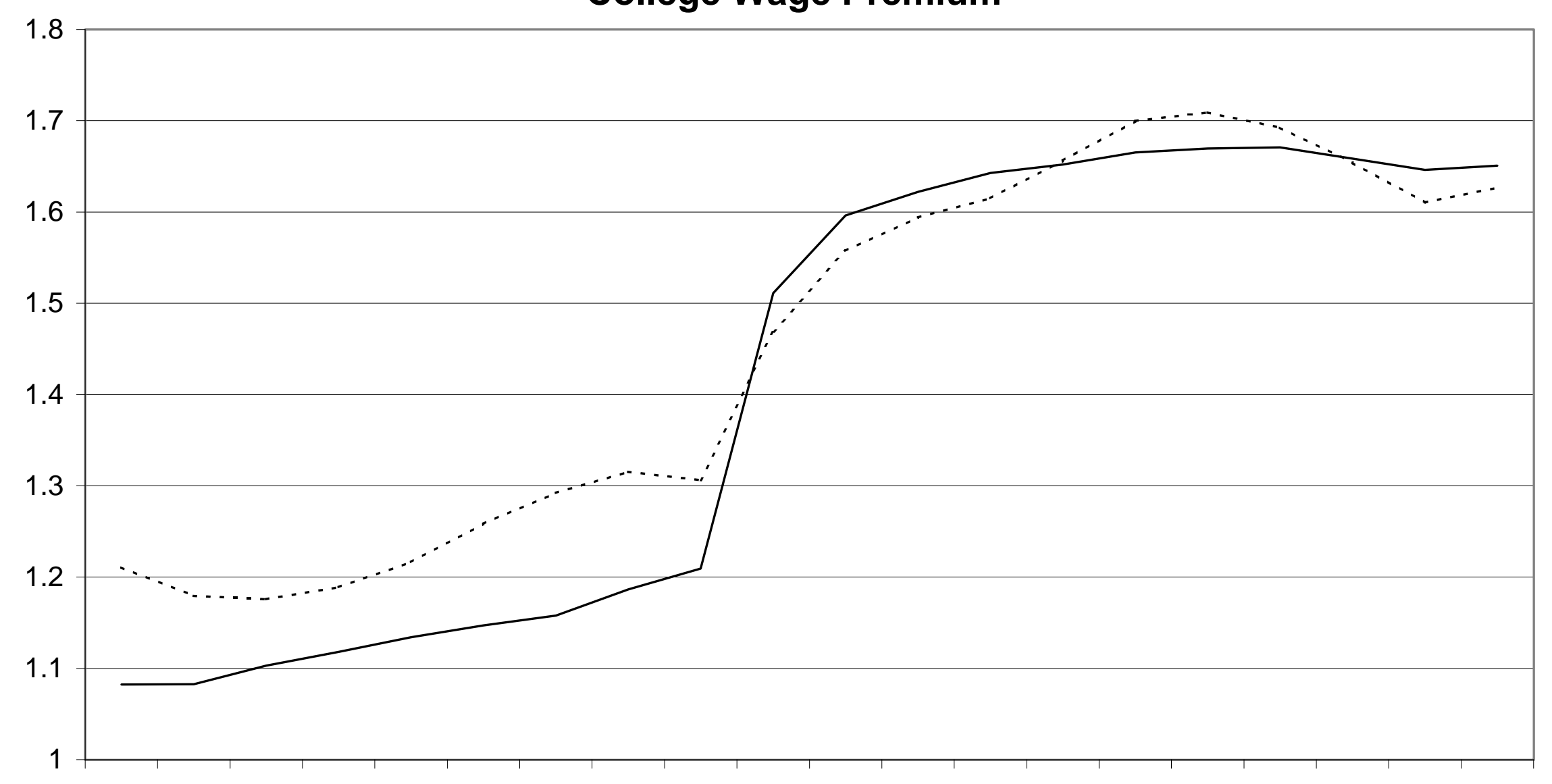

19791980198119821983198419851986198719881989199019911992199319941995199619971998 blacks

whites

Source: Outgoing rotations group and authors' calculations 
Figure 6

College Enrollment of High School Graduates by Race

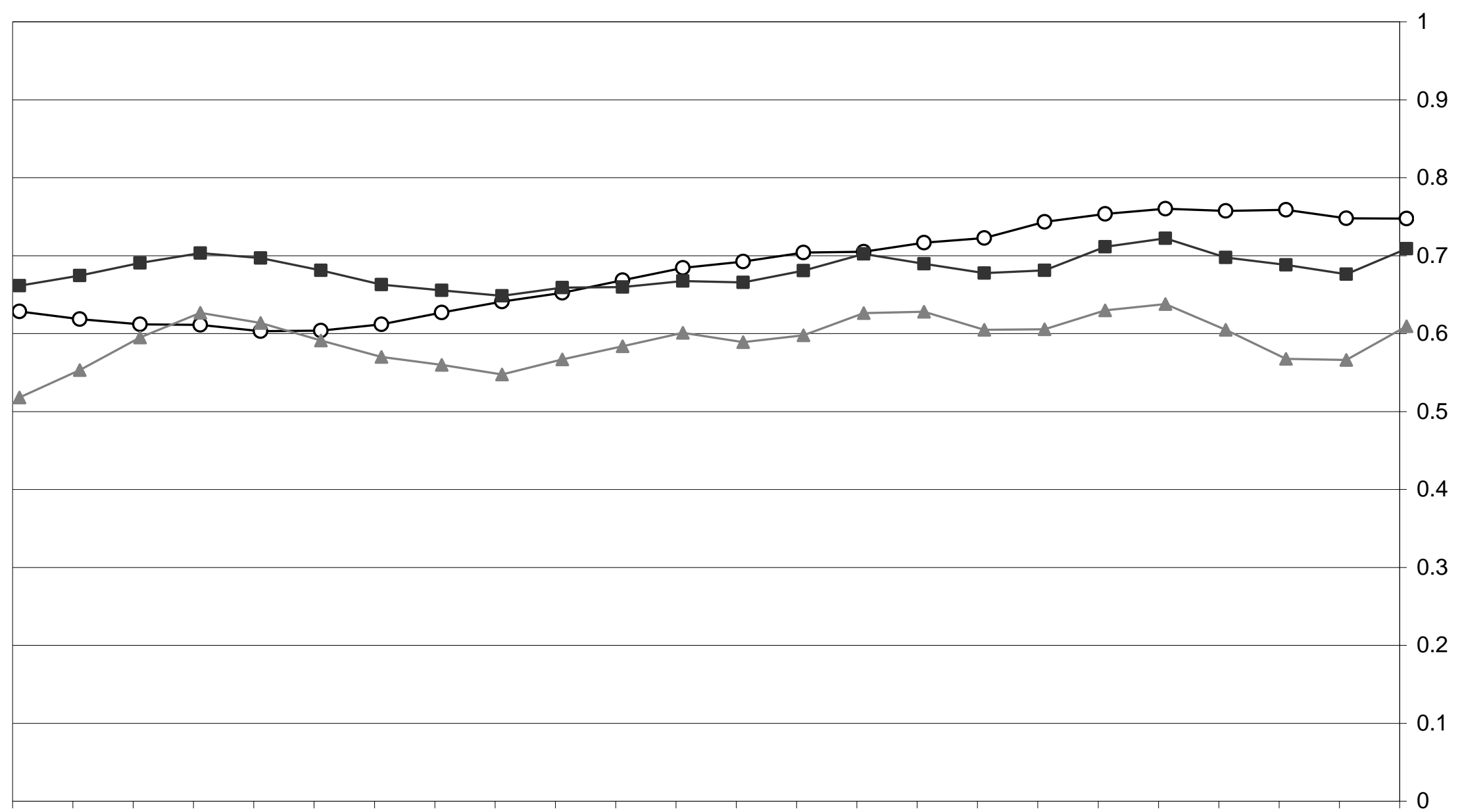

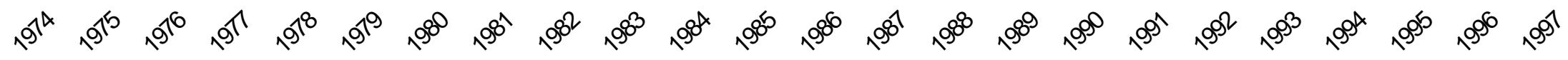

${ }^{-}-$whites $\rightarrow$ black-predicted $\rightarrow$ black

